genesis. Balfour suggested "that the function of forming polar cells has been acquired by the ovum for the express purpose of preventing parthenogenesis." Weismann naturally cannot agree with this view, since he regards the extrusion of polar bodies merely as the removal of the ovogenous or spermogenous nucleo-plasma. At the time his memoir was written there were no instances in which it had been ascertained with absolute certainty whether polar vesicles areformed or not in the case of ova about to develop parthenogenetically; but in a postscript at the end of the memoir he is able to announce that he has discovered that in the case of parthenogenetic summer eggs of the Daphnidæ a polar vesicle of distinct cellular structure occurs. This is sufficient proof of the incorrectness of the older theory, and he further adduces the fact that in the case of the honey-bee the same identical egg can be made to develop either after fertilisation or parthenogenetically, according to the act of the queen, showing that the parthenogenetic and sexual eggs are of the same essential nature. The difference between the two must lie in the quantity of germ-plasma which they respectively contain. In order that the segmentation nucleus of the ovum may proceed to the process of ontogenesis, it must possess a certain mass. Even amongst higher vertebrates it is known that an unfertilised egg may occasionally go through the first few stages of segmentation, then, however, always failing through lack of the requisite power.

When impregnation takes place and the substance of the nucleus of the sperm-cell becomes added to that of the ovum, the combined mass of germ-plasm becomes powerful enough to carry through all the stages of ontogeny to the end. In the case of certain animals where the ovum remains unfertilised, and thus unchanged after the extrusion of the ovogenous nucleo-plasma, if a special supply of nourishment reaches its germ-plasma, this increases in amount by growth, and thus attains the mass requisite to start the ontogenetic process, with the result that parthenogenetical development takes place. In the ordinary sexual process it is the sudden doubling of the mass of the nucleus by the copulation that starts the segmentation of the ovum. It is the increase of the mass of the nucleus which gives the stimulus to segmentation, the disposition to which was already there before. The difference between eggs requiring fertilisation, and those not requiring it supervenes after the ripening of the egg and the extrusion of the ovogenous plasma. The phyletic inheritance of the capability of parthenogenetic development rests on a modification of the power of growth of the egg nucleus.

More than ten years ago Weismann expressed the conviction that "the physiological value of the spermcell and egg cell are identical," and now that the body of the egg cell can hardly have ascribed to it a higher value than that of a common nutrient ground for the two nuclei during the act of impregnation, this position seems a very secure one, Strasburger fully agrees, and states that "Sperm-nucleus and egg-nucleus do not differ in their nature." If it were possible to introduce by artificial means into any egg, immediately after the change of the germinal vesicle into the egg-nucleus, the egg-nucleus of another egg of the same species, it is probable that the two nuclei would copulate just as if a ripe sperm-nucleus had penetrated into the egg in the usual way, and a direct proof would thus be given that the egg and sperm-nucleus are in fact identical. The technical difficulties are too formidable to permit of this experiment being made, but a partial confirmation is afforded by Von Berthold's discovery that in certain algæ Ectocarpus and Scytosiphon, not only a female, but also a male parthenogenesis occurs. Further, the occurrence of conjugation must be regarded as a proof of the correctness of this view. There can scarcely be any further doubt that conjugation is the sexual reproduction of unicellular organisms. Amongst these usually the two conjugating cells are externally absolutely alike, and probably they are so internally also, but there are some low forms, such as Volvox, where a difference between the two is already fully established, huge egg shells and minute zoosperms being produced. The identity of the sperm nucleus and egg nucleus here insisted on only regards their essential fundamental structure and composition; each is in certain finer details necessarily peculiar, as transmitting the idiosyncracies of its own parent stock.

H. N. MOSELEY

\section{THOMAS ANDREWS, F.R.S.}

R. ANDREWS, whose death we announced a fortnight ago, was a native of Belfast (born December 19, 1813), and spent his whole life there. His father was a linen-merchant, in good position; and he received his early education at the Academy and at the Royal Academical Institution of Belfast. Thence he went to Glasgow, where he studied under Dr. Thomas Thomson, the well-known Professor of Chemistry, and learned pract:cal work in his laboratory. He had, next, a successful undergraduate career in Trinity College, Dublin; where he distinguished himself in Classics as well as in Science. Having spent some time in Paris, in the laboratory of Dumas; and having obtained his Medical Degree in the University of Edinburgh, in 1835 ; he devoted himself to medical practice in his native town. In this he was highly successful ; but he continued to devote his leisure, small as it was, to scientific research ; publishing numerous papers on chemical and physical subjects. To these we will recur, but it is noteworthy that in 1844 he received one of the Royal Medals, in the gift of the Royal Society, for his purely scientific discoveries, before he finally gave up professional practice. $\mathrm{He}$ was the first lecturer appointed to teach Chemistry in the Royal Belfast Academical Institution, and he resigned this post, as well as gave up practice, when appointed in 1845 to the VicePresidentship of the "Northern College," now Queen's College, Belfast. The Presidents and Vice-Presidents of these new Irish institutions were appointed some years before the Colleges were opened, or the Professors elected, in order that the Government might have their advice and assistance in maturing the whole scheme. Andrews was thus associated with another justly-distinguished Irishman, Sir Robert Kane; and it is mainly to their labours and foresight that the Queen's Colleges, when at last opened, appeared before the world in full working order.

It had been understood from the first that Andrews was to be the Professor of Chemistry in Belfast; but, when the time for appointing Professors arrived, he was required (as a matter of form, merely) to produce a few Testimonials. These he obtained at once, in the highest terms, from such men as Thomas Graham, Humphrey Lloyd, MacCullagh, \&c., and they need not be given here. But it may be interesting to show, as briefly as possible, the opinions of two of the greatest of foreign chemists. Liebig wrote (November IO, I845) as follows:- "Ich hege die volle Ueberzeugung dass der Platz um den Sie sich ... bewerben, keinen würdigern Besitzer finden dürfte. Sie haben viele Jahre hindurch mit den grössten Schwierigkeiten zu kämpfen gehabt, um der warmen Neigung welche Sie für die Naturwissenschaften hegen Nahrung zu geben, und weit entfernt dass Ihr Muth und Eifer dadurch gelähmt worden wäre, haben Sie durch Ihre letzten wichtigen Arbeiten über die Wärme bey chemischen Verbindungen dargethan, dass die Beschäftigung mit der Wissenschaft ein Bedürnniss ihres Geistes ist." Dumas (November 29, 1845) wrote :- "Vos titres à la nouvelle fonction à laquelle vous aspirez sont si clairs et si évidents que je ne concevrais guère que vous n'y fussiez point appelé . . . mais, tout en enseignant la chimie, n'oubliez pas que vous comptez au nombre des physiciens 
distingués de votre pays." The rest of this letter is not personal, but refers to the impossibility of separating chemistry from physics, and to the important aid which each of these sciences constantly obtains from the other.

Andrews was as successful in his Professorship as he had formerly been as a Practitioner. He soon gathered large classes, alike for general chemistry and for practical laboratory work. All his spare time, for the greater part of every working day, was spent in his private laboratory. Here he delighted to receive his scientific friends, and to engage eagerly in conversation with them while his hands were busy with the steady, deliberate construction or adjustment of apparatus for his next research. His habits were of an extremely temperate, almost abstemious, character. From his early breakfast, to his somewhat late dinner-hour, he never partook of either food or drink ; and used to say that a man required only two meals a day. It is to be feared that his persistence in this habit in his later years tended materially to reduce his strength.

$\mathrm{He}$ was elected to the Royal Society in 1849 . In 1852 (at Belfast), and again in $187 \mathrm{I}$ (at Edinburgh), he presided over the Chemical Section of the British Association. He was President of the Association in 1876 (at Glasgow), having declined the appointment in a former year in consequence of the state of his health. He was a corresponding member of the Royal Society of Göttingen. and an Honorary Fellow of the Royal Society of Edinburgh. He received honorary degrees from various Universities. But he valued this class of distinctions simply as tokens of the esteem and good wishes of the donors; and in the somewhat delicate matter of a civil title he shared the opinion, and followed the practice, of his cherished friend Faraday. In 1879 he resigned his appointments in Queen's College, and thenceforth led a very retired life, though still vividly interested in the progress of science, till his death on November 26 last.

The only purely literary works of Andrews, so far as the writers of this notice are aware, were his two extremely thoughtful and learned Chapters of Contemporary History. The first, entitled Studium Generale, was published in 1867 , when attempts were being made to cripple the usefulness of the Queen's Colleges. The reasons for the appearance of the second, published in I869 with the title The Church in Ireland, are still too painfully prominent to require special mention.

Dr. Andrews married, in 1842 , Jane Hardie, daughter of Major Walker, of the 42nd Highlanders. He is survived by his widow, by three daughters, and by two sons, the elder of whom is Major in the Devonshire Regiment, and the younger a member of the Irish Bar.

His first published paper on a chemical subject is on the composition of the blood of cholera patients. $\mathrm{He}$ showed that it differed from normal blood only by having a smaller proportion of water. Much more important both in itself and as showing the bent of his mind to the borderland between Chemistry and Physics is a paper on galvanic cells with strong sulphuric acid as the exciting liquid. The question is of course really that of the electrolysis of strong sulphuric acid, and Dr. Andrews showed that the composition of the gas given off at the cathode varies in a remarkable manner with the temperature. This is quite in accordance with what we now believe as to the constitution and dissociation of strong sulphuric acid, but at the time the paper was written nothing was known which could lead any one to suspect such a variation.

We now come to one of his great works-the determination of the heat evolved during chemical action. In three series of investigations he determined the heat given out in the formation of neutral, acid, and basic salts, by the action of acid on base; in the displacement of one metal in a salt by another; in the formation of oxides; and in the formation of chlorides. In this great research we see the character of the man, his clear view of what was to be observed, his distinct recognition of the sources of experimental error, and the simple but effectual means he took to get his results free from the effects of such disturbing causes. Especially worthy of note is his use of solutions so dilute that further addition of water produced no sensible thermal change.

The well-known experiments of Favre and Silbermann were published not long after Andrews' first papers on this subject. It is interesting to notice that where these observers differ from Andrews, subsequent investigations, particularly those of Berthelot and of Thomsen, have shown that Andrews was right.

In 1855 Andrews communicated to the Royal Society a paper of great importance and interest on Ozone. This remarkable substance had been studied by Schönbein, its discoverer, Marignac, De la Rive, Berzelius, Williamson, Fremy and Becquerel, and Baumert, but its nature still remained a mystery. Is ozone always the same thing, or are the ozone of electrolysis, that of the electric machine, and that formed during the slow oxidation of phosphorus, different bodies very like one another in properties?

Some experiments seemed to show that ozone contained nothing but oxygen, others that it was an oxide of hydrogen containing a larger proportion of oxygen than water does. The question was exactly of the kind to attract Andrews and to call out his peculiar powers of investigation.

By a series of experiments remarkable for simplicity and delicacy, and perfect adaptation to the purpose in view, he proved that "ozone, from whatever source derived, is one and the same body, having identical properties and the same constitution, and is not a compound body, but oxygen in an altered or allotropic con. dition."

The investigation into the nature of ozone was continued by Andrews and Tait, and the results published in their paper On the Volumetric Relations of Ozone and the Action of the Electrical Discharge on Oxygen and other Gases (Phil. Trans., I860). These results led directly to the theory of the constitution of ozone now universally held; indeed that theory is distinctly stated by Andrews and Tait, although not further discussed on account of its supposed improbability.

Among smaller works we may mention the discovery of minute particles of metallic iron in various rocks, particularly basalts.

None of his chemical papers can be read without some new idea being communicated to the reader, however well acquainted he may be with the subject.

The investigation, however, by which Andrews is, and will continue to be, best known, was that On the Continuity of the Liquid and Gaseous States of Matter which formed the subject of the Bakerian Lecture in 1869 , and again in 1876 .

One of the earliest of Faraday's researches was devoted to the liquefaction of gases, and he succeeded with all but a few, which were in consequence, till very recently, distinguished as "non-condensable." But he expressed the conviction, founded on experiment, that even these could be liquefied by the conjoint action of sufficient pressure and sufficient reduction of temperature.

Another extremely ingenious experimenter, Cagniard de la Tour, had approached the subject from the opposite side; and had shown that liquids, such as water and sulphuric ether, could be changed into something which was certainly not liquid, by sufficient rise of temperature without any great increase in volume.

Regnault, also, had measured with his unrivalled precision the compressibility of various gases; and had called attention to the curious differences which they show in their modes of divergence from Boyle's Law. And Natterer, by employing pressures of some thousands of atmosphere;, had arrived at other startling results. 
The whole subject was in that chaotic state which naturally precedes the advent of the Kepler who is to marshal, under a few general statements, each intrinsically simple, the mass of apparently irreconcilable phenomena.

Andrews' classical researches completely effected this simplification. Guided by the results of Regnault, he selected carbonic acid as the substance whose behaviour was made the subject of exhaustive study through wide ranges of temperature and of pressure. He devised an extremely ingenious form of apparatus for the purpose, had the coarser metallic parts constructed under his own eye by a remarkably skilful mechanic; and himself made and calibrated the glass portions, purified with great care and skill the gas to be operated on, and finally fitted up the whole with unwearying patience.

The simpler and more prominent results of this splendid research may be briefly summed up as follows :-

(a) When carbonic acid is maintained at any temperature whatever above $30^{\circ} .9 \mathrm{C}$., it cannot even in part be condensed into liquid by any pressure however great.

(b) If the temperature be below $30^{\circ} .9 \mathrm{C}$, the gradual increase of pressure ultimately leads to liquefaction; but the pressure of the vapour in presence of the liquid is less as the temperature is lower.

(c) A cycle of operations, in Carnot's sense, can be performed on liquid carbonic acid in such a way that, during the first stage of the expansion we have optical proof of the existence of liquid and gas side by side in the same vessel ; while on compressing again at a higher temperature, and finally cooling down to the original temperature and volume, the whole contents are once more liquid; though at no stage of the latter part of the operation is there any appearance of the joint presence of two different states of matter. It is this fact which suggested the title of the paper.

(d) The key to the explanation of observed deviations from Boyle's Law was furnished by his study of the isothermals of carbonic acid at temperatures not much above $30^{\circ} 9 \mathrm{C}$. For Andrews's measurements show that the product of pressure and volume (which, by Boyle's Law, should be constant) diminishes with volume to a minimum, and thereafter rises rapidly as the volume is farther diminished.

Many other valuable results, such as the great compressibility of liquid carbonic acid, especially at temperatures near to $30^{\circ} \mathrm{C}$; ; the alteration of surface-tension of the liquid, and of its angle of contact with glass, as the temperature is raised, \&c., appear as mere side-issues of this investigation.

The discovery of this Critical Temperature, or Critical Point, soon led to the liquefaction (and in certain cases even to the solidification) of the gases which had been called "non-condensable." Andrews' work had supplied all the necessary hints for the adaptation of his apparatus to such a purpose. In fact the main requisites were (I) to work on a larger scale, (2) to employ very low temperatures, and especially (3) to provide a means of ensuring sudden relaxation of pressure. The work of Pictet, Cailletet, v. Wroblewski, Amagat, \&c., on this subject, followed as a natural and immediate consequence of that of Andrews.

The writers have, like many others, seen and admired the confident manipulation, by Andrews, of wide sealed tubes, half full of liquid carbonic acid; how he, knowing the soundness of his own glass-blowing, boldly heated such tubes in the flame of a Bunsen lamp, till the liquid entirely disappeared, and pointed out with eager enjoyment the extraordinary phenomena presented as the contents cooled nearly to the critical temperature. The whole tube seemed, for a short time, to be filled with a substance presenting, to an exaggerated degree, the appearance of a mixture of water and alcohol before diffusion has sensibly operated.

We have spoken of Andrews's remarkable skill in manipulation, and of his unwearied patience. But even these were eclipsed by the perfect calmness with which, though on the very verge of an important discovery, he attended to every point of minute and laborious detail ; so that his first successful experiment was as exactly carried out and recorded as was its future repetition. This was all the more remarkable in that he was usually, especially in public, a man of a highly nervous and excitable temperament.

An excellent French and German scholar, he kept himself always well acquainted with the most recent progress of science, whether chemical or physical. He constructed his own dividing-engine for the calibration of the exquisite thermometers which he made for his researches on heat; and his air-pump (in which he took special delight) was furnished with numerous valuable improvements all devised by him for particular applications. His laboratory books were models of ample, but not superfluous, detail.

$\mathrm{He}$ was, personally, a man of simple unpretending manner; conscientious almost to an extreme, but thoroughly trustworthy and warm-hearted; an excellent example of the true Christian philosopher.

\section{NOTES}

WE regret to announce the death of Mr. Alfred Tribe, the well-known chemist, on November 26, at the age of forty-six years. We defer to next number a notice of Mr. Tribe's career.

A MeEting of the subscribers to the testimonial to Dr. H. Woodward, F.R.S., for twenty-one years editor of the Geological Magazine, was held on the 15 th inst., at the rooms of the Geological Society, Burlington House, when Prof. T. G. Bonney (Pres. Geol. Soc.) presented to that gentleman, on behalf of the subscribers, a silver tea and coffee service and a cheque for $253 l$. On making the presentation, Prof. Bonney addressed Dr. Woodward, referring to the invaluable services be had rendered to science during the twenty-one years he has had charge of the Geological Magazine. In replying, Dr. Woodward referred briefly to the career of the Magazine and its predecessors, to the many distinguished men that had been connected with them, and to the period of remarkable scientific interest thus covered. Over 200 names are on the list of subscribers to the testimonial.

THE roth instant was a red-letter day at the French Institute. M. Bertrand was introduced as member of the Académie Française, and read an address which, according to custom, was devoted entirely to thanking his brother Academicians and to eulogising his immediate predecessor, M. Dumas. The address was acknowledged by another oration from M. Pasteur, who after having summarised the life of M. Bertrand, gave a long and interesting account of the career of M. Dumas. Great enthusiasm prevailed throughout the proceedings, and the hall was crowded.

THE number of patients in the special clinic of M. Pasteur is increasing daily, several arriving from foreign countries. No less than forty were inoculated on December $\mathrm{r}_{4}$ before the Minister of Agriculture, who acknowledged the services rendered by Pasteur to humanity. Among the patients is an officer of the Czar's body-guard, just arrived from St. Petersburg.

A BIOGRAPHY of the late Sir William Siemens is being prepared, at the desire of the executors, by Dr. William Pole, F.R.S., Hon. Secretary of the Institution of Civil Engineers, and author of the "Life of Sir William Fairbairn, Bart." Dr. Pole will be grateful for the loan of any of Sir William's letters, or for any information of importance. Address, Athenæum Club, S.W.

ON Saturday, last week, the rainfall at the Ben Nevis Observatory amounted to $4.99 \mathrm{I}$ inches, and on the Sunday following 